\title{
Motivation and Job Satisfaction in Organizations: A Study of University of Africa and Market Square Company, Bayelsa State
}

http://doi.org/10.21272/bel.3(3).78-87.2019

\section{Frank Funkeye Sapele}

MSc, Lecturer 11, Department of Political Science, University of Africa, Toru-Orua, Bayelsa State, Nigeria

\section{Sakiemi Abbey Idoniboye-Obu}

PhD, Senior Lecturer, Department of Political Science, Ignatius Ajuru University of Education, Rivers State, Nigeria

\begin{abstract}
The article summarizes the arguments and counterarguments within a scientific discussion on the issue of increasing the level of motivation and job satisfaction in organizations. The main objective of the study is to identify facts of increasing the employee job satisfaction and to determine key tools for increasing their motivation towards effective and quality work. The systematization of literary sources and approaches to solving the problem of improving the productivity of economic entities indicates the significant urgency of the problems associated with the low level of motivation of employees. The relevance of solving this scientific problem lies in the fact that motivation plays an important role, since it forms the basis of managerial functions in the context of planning and organizing business, improves the performance of employees in an organization. Methodological tools of the research were methods of data analysis and synthesis, surveys and statistical methods. The subject of the study is employees of the University of Africa and Market Square Bayelsa State. The paper presents the results of an empirical analysis, which show that motivation and job satisfaction are considered a means of increasing the effectiveness of the organization and providing quality services, as well as a tool to achieve high productivity. The study anchored on Herzberg two factors theory of motivation and the research adopted a qualitative technique. The research empirically confirms and theoretically proves that there is a strong link between motivation and job satisfaction for efficient service delivery in the various organizations and that wages, bonuses also play an important part of motivating employees which increases job satisfaction within organizations. The study recommends prompt payment of salaries and all entitlements, which actually help to encourage employees towards effective job satisfaction.
\end{abstract}

Keywords: employees, job satisfaction, motivation, organization, performance.

JEL Classification: E24, J28, L16, L25.

Cite as: Sapele, F.F., Idoniboye-Obu, S.A. (2019). Motivation and Job Satisfaction in Organizations: A Study of University of Africa and Market Square Company, Bayelsa State. Business Ethics and Leadership, 3(3), 78-87. http://doi.org/10.21272/bel.3(3).78-87.2019.

(C) The Authors, 2019. This article is published with open access at Sumy State University.

\section{Introduction}

Human resource manager achieves results only through proper management of both human and non-human resources. Of the two categories of resources, the management of the human resource is the most difficult because of its dynamic and sensitive nature, its complexity and its unpredictability. The human resource department is so dynamic in the sense of its diverse and varied needs according to individuals and groups in organizations. In other words, the needs drive is what motivates employees to act in a particular way. The human resource manager's understanding of this simple, but crucial fact is very important because if he/she knows why employees do things the way they do (act in a particular way), it makes it easier for him/her to persuade them to do the things he /she wants them to do. It makes it easier to get things rightly done to achieve the goals of the organization. This can rightly measure with the issue of motivation because motivation determines organizational behaviour and helps in improving job satisfaction. Employee motivating management is a strategy, which is aimed at harnessing and channeling the energies, potentialities and abilities of the human beings in the organization for a common purpose and accomplishment of goals that none of them singly could accomplish. Therefore, when two or more people 
Business Ethics and Leadership, Volume 3, Issue 3, 2019 ISSN (online) - 2520-6311; ISSN (print) - 2520-6761

combine to roll away a stone that could not have been rolled away by any single individual, then the rudiment of motivation exist among the people. When the process succeeds, the employees will develop a mature and sound relationship among themselves with mutual trust, dependence, support, and respect. Even when each member may have a different task to perform, everyone will contribute significantly because each member is responsible for the success of the organization (Maicibi, 2013: 206).

Organizations need highly performing individuals in order to meet their goals, to deliver the products and services they specialized in, and finally to achieve competitive advantage. Performance is also important for the individual. Accomplishing tasks and performing at a high level can be a source of satisfaction, with feelings of mastery and pride. Low performance and not achieving the goals might be experienced as dissatisfying or even as a personal failure. Moreover, performance, if it is recognized by others within the organization, is often rewarded by financial and other benefits. Performance is a major although not the only prerequisite for future career development and success in the labor market. Although there might be exceptions, high performers get promoted more easily within an organization and generally have better career opportunities than low performers (VanScotter, Motowidlo, \& Cross, 2000) Sonnentag \& Frese (2001). Cited in Calvin (2017: 34).

For Akpotohwo, Ogeibiri and George (2017) motivating a worker today is considerably more complex than the simple application of the 'carrot and stick' approach used by many managers of yesterday. It is true that people participate in an organized enterprise in order to achieve some goals that they cannot attain as individuals. But this does not mean that they will necessarily work and contribute and ensure that these goals are accomplished. A motivated worker would surely perform his duties; contribute to the achievement of or organizational goals.

The motivation of employees in an organization plays a significant role through effective and efficient job productivity. Motivation and job satisfaction lead to more productivity and also helps staff retention in organizations because employees' behaviour and feelings within the context of an organization are usually determined by motivation and job satisfaction. When the organization emphasizes more on implementing an incentive system with a high level of justice, equity, then employees' job satisfaction will increase. Motivation basically has two dimensions.

According to Anonymous (2010), "making employees work better, more efficiently and effectively" from the point of view of managers, the other being "enabling employees to do their jobs in the best way with enjoyment and desire" from the point of view of employees. Motivation and Job Satisfaction has been considered to be affected by economic variables and this fact cannot be denied but are not sufficient enough to have a prolonged effect. However, it is seen that appeal to the motivating economic tools and expecting from them more than needed does not seem to result in success very much. Therefore, in planning rewarding, encouraging economic tools should be employed in accordance with employees' needs. In fact, there are ways of increasing employees' work motivation and satisfaction other than monetary tools (Cited in Singh and Tiwari, 2010: 33).

Motivation within organizations can be attained through the following process: by providing a positive working environment towards attaining organizational goals; reward and recognition among staff within the organization; to be involved and increasing employee engagement and programmes; developing the overall skills and potentials of organization workforce; the issue of evaluating, assessing and measuring job satisfaction within the organization.

\section{Statement of the Problem}

The greatest efficiency and productivity in an organization will flow from efforts of those who find satisfaction in their work and conditions or services, who feel encouraged to move ahead and to meet new challenges, who perceive their working environment as one in which high standards of performance are maintained and rewarded. Increasing motivation, workers commitment and the extent of appointments are key organizational aspects in contemporary time. The development of compensation policies plays a very important role in motivating the workforce to give out the high levels of performance, unrestricted effort and input within organizations. The process of motivation usually starts with someone recognizing a dissatisfied need. Thereafter a goal is established to be reached and that way to satisfy the need.

For organizations to increase productivity, then motivation is important because staff satisfaction is tied also to the level of motivation within an organization. More so, staff performance and satisfaction are one of the ways to measure the extent of its effectiveness within an organization. The need for the ability to set goals 
Business Ethics and Leadership, Volume 3, Issue 3, 2019

ISSN (online) - 2520-6311; ISSN (print) - 2520-6761

and objectives to achieve its performance and how to improve the overall organizational performance centers on motivation. The measurement of motivation towards staff job satisfaction is a challenge for organization especially in the University of Africa and Market Square, which this paper wants to investigate because employee behaviours and feelings are greatly affected by motivation and job satisfaction. Employers also face the challenges of improving efficient productivity and profitability in different ways as well as holding firmly their workforce engaged and satisfied with their jobs, because those that failed to motivate workers and improve on job satisfaction within organizations actually intend to loose effective and efficient productivity within organizations.

More so, it has been generally observed that many times employees who are actually satisfied with their jobs are still not effective performers. This may be as a result of their lack of Motivation and commitment for the organization; this point of view stresses the importance of the study of Motivation and its relationship to Job Satisfaction within organizations. With this context in the current study, the paper will explore to examine the relationship between Motivation and Job Satisfaction in the study of the University of Africa and Market Square Bayelsa State.

\section{Objectives of the Study}

Basically, the general objective of this study is to examine motivation and job satisfaction in organizations. A study of University of Africa and Market Square Bayelsa state.

Specifically, the objectives include:

I. To examine the extent to which employees of the University of Africa and Market Square are motivated.

II. To determine the extent of job satisfaction among employees of the University of Africa and Market Square Bayelsa State.

III. To establish the effects of monetary and non-monetary rewards on job satisfaction of employees in the University of Africa and Market Square Bayelsa State.

\section{Conceptual Clarification}

\section{Motivation of Employees in Organizations}

According to Croft (1996), motivation can be defined as impulses that produce steam from within a person and leads him to act in ways that will satisfy those impulses. In other words, the concept of motivation implies that there is some driving force within individuals, which drives them to attempt to achieve a goal or objective, in order to satisfy their needs or others. Therefore, to say that managers motivate their employees is to say that they do those things which they hope will satisfy these drives and desires and induce the subordinates to act in a desired manner.

\section{Koontz (1983) pointed out:}

....all those who are responsible for the management of any organization must build into the entire system factors that will induce people to contribute as effectively and efficiently as possible. A manager does this by building into every possible aspect of the organizational climate those things which will cause people to act in desired ways.

Motivation of employees becomes very essential when it is realized that although people work in an organized enterprise or participate in all kinds of groups in order to achieve some desired goals that they cannot attain as individuals, this does not imply that they will necessarily put in maximum efforts to ensure that these goals are accomplished in Ezeani (2006: 136).

For Salanova and Kirmanen (2010), increasing motivation, commitment, and engagement levels are key organizational aspects nowadays. The development of compensation policies has an important role in motivating the workforce to deliver high levels of performance, discretionary effort and contribution. The process of motivation usually starts with someone recognizing an unsatisfied need. Then a goal is established to be reached and that way to satisfy the need. Rewards and incentives can be established for people to better accomplish the given goal. The social context will also affect the motivation level. This context consists of organizational values and culture, but it also includes leadership and management as well as the influence of the group or team in which a person works. Motivation can be intrinsic or extrinsic. Intrinsic motivation can 
be described as the process of motivation by work itself in so far as it satisfies the personal needs of the employee. Intrinsic motivation is self-generated and it is thought that people seek for a job they think will most satisfy their needs. Basu (2012: 165) argued that it is quite obvious that the mere possession of knowledge, skill, and ability will not ensure the best results as performance depends upon motivation as well. It is only when the employees are well properly motivated that they will use their skills knowledge and ability to ensure the best results. The most important task of the personnel department must be to give abundant and constant evidence of its belief that personnel in the organization are key to development. Motivation is of utmost importance, as it constitutes the base for the management function of planning and organizing. The Personnel of a department must devote considerable time and effort to planning for and achieving a high level of motivation and morality.

Akpotohwo, Ogeibiri, and George (2017: 107) argued that motivation in relation to work could be defined as the condition of being influenced to do something. It is the process of influencing workers to give their very best to their organization. It is the driving force that stimulates an individual, i.e. a worker, into action in order to achieve his or her organization's objectives. It is also described as the willful or voluntary act on the part of an individual. However, these scholars added that the key to understanding motivation lies in the meaning and relationship between needs, drives, and goals. Needs set up drives to accomplish goals. Needs simply mean deficiency. Needs per se are created as a result of physiological or psychological imbalance. A drive can also imply motive, while the goal is defined as anything that can alleviate a need and consequently reduce a drive. It is true that people participate in an organized enterprise in order to achieve some goals that they cannot attain as individuals. But this does not mean that they will necessarily work and contribute all they can to be sure that these goals are accomplished. A motivated worker would surely perform his duties; contribute to the achievement of organizational goals. On the other hand, even though frustrated and coerced workers may be forced to contribute to production, yet it must be realized that while it is possible to pushstart a stalled car or switch on and off a faulty machine, the human being is none of these. Hence, the force will hardly make much in getting human beings to perform their assigned tasks satisfactorily.

Work motivation is quintessentially defined as the psychological processes that direct, energize, and maintain action toward a job, task, role, or project (Campbell \& Pritchard, 1976; Kanfer, 1990), one of the most recent contributions to the theories of motivation is self-determination theory which explains that employees have three basic psychological needs: autonomy, competence, and relatedness (Ryan \& Deci, 2000: 174). Herein, autonomy refers to the feeling of preference and discretion, competence refers to feeling competent and efficacious, and relatedness refers to feelings of connectedness and sense of belongingness with others (Nidhi, 2015: 303).

However, this paper sees motivation as all those things that make workers be very happy in any organization. That is, motivation involves all those things that make an employee be very happy in achieving organizational goals. Because a motivated person is a happy person as regards to the aspirations of the organizational objectives.

\section{Job Satisfaction in Organization}

According to Dolan and Lingham (2008), Job satisfaction is a positive emotional state resulting from an individual's opinion of the job. Although it was traditionally thought that a person who is satisfied with the job will perform better, recent studies have shown that an increase in job satisfaction does not always lead to improved performance. Our interest in job satisfaction stems from the fact that there are direct links between performance and job dissatisfaction. For instance, people who are dissatisfied with their jobs are more likely to be absent from work, to have physical and mental health problems, and to quit their jobs. Measuring job satisfaction can identify aspects of the organization that may require change.

Job satisfaction is generally measured as a general overall attitude and as an attitude that contains five dimensions. These dimensions are the pay level, the work itself, the opportunities for promotion, the quality of supervision, and the level of satisfaction with one's co-workers.

While Salanova and Kirmanen (2010), posited that there are important reasons why companies should be concerned with employee job satisfaction, which can be classified according to the focus on the employee or the organization. First, the humanitarian perspective is that people deserve to be treated fairly and with respect. Job satisfaction is the reflection of good treatment. It also can be considered as an indicator of emotional well-being or psychological health. Second, the utilitarian perspective is that job satisfaction can lead to behavior by an employee that affects organizational functioning. Furthermore, job satisfaction can be 
ISSN (online) - 2520-6311; ISSN (print) - 2520-6761

a reflection of organizational functioning. Differences among organizational units in job satisfaction can be diagnostic of potential trouble spots. Each reason is sufficient to justify concern with job satisfaction. Combined they explain and justify the attention that is paid to this important variable. Managers in many organizations share the concerns of researches for the job satisfaction of employees.

The level of job satisfaction is affected by intrinsic and extrinsic motivating factors, the quality of supervision, social relationships with the workgroup and the degree to which individuals succeed or fail in their work. It is believed that the behaviour that helps the firm to be successful is most likely to happen when the employees are well motivated and feel committed to the organization, and when the job gives them a high level of satisfaction. The research showed that the key factors affecting job satisfaction are career opportunities, job influence, teamwork and job challenge (Armstrong 2006, 264).

Campbell, McCloy, Oppler, and Sager (1993) stressed that performance referred to only such behaviours which were goal-oriented i.e. whether the individual accomplished the organizational goal behind hiring the employee for that specific job role. Campbell further established that as far as the measurement of performance was concerned, at the most basic level, job performance could be differentiated in terms of either process or outcome of that performance. However, on the other end, in contrast to this group of authors, there are authors like Bernardin, Villanova, Hagan, and Kane (1998) who did not agree that job performance, could be described as employees' behaviours; they rather proposed that performance was something different and separated from the person doing it. These authors asserted that performance was the record of outcomes achieved by a person on a particular job assigned to him during a specified time period. It was also provided by these scholars that job performance is distinct from the characteristics of the person producing it. Mitchell and James (2001) highlighted the need for studies to systematically examine such fluctuations in individual performance. Situation-specific variables, on the other hand, include work characteristics, leadership, reward systems, and job design, which also have a bearing on individual job performance (Cited in Nidhi, 2015: 303).

\section{Effects of Motivation and Job Satisfaction in Organizations}

According to Basu (2012: 168) the greatest efficiency and productivity in an organization will flow from the efforts of those who find satisfaction in their work and conditions or service, who feel encouraged to move ahead and to meet new challenges, who perceive their working environment as one in which high standards of performance are maintained and rewarded. Motivation can do miracles as a motivated worker can achieve more than an expert with no motivation.

Thom-Otuya (2003) posited that the following effects of motivating employees have been definitely established in organizations.

The employees who are sufficiently motivated move and act to follow the direction desired by management.

The motivated employees achieve high output and produce good quality products and services.

The employees who are properly motivated are more careful in the use of machines and equipment, avoid or prevent accidents and minimize or prevent losses or waste.

$>$ The employees accept willingly the changes made by management provided that the change to be made have been previously explained to and understood by them and proper training is provided to adjust them to the change.

$>$ With motivated employees the problems of discipline is minimized.

The motivated employees willingly respond in times of emergency or during such periods or occasions requiring special effort, overtime and the like.

For Tiger (2018) motivation and staff performance play an important role in increasing organizational effectiveness and efficiency. Employees promote the overall success of any organization if they would be given all the benefits that will make them grow within the organizational setup. The effects of motivation and employees performance can arise through: adherence to the organizational vision, goals and mission statements; increasing productivity within the organization; bringing innovative ideas that would promote the interest of the organization; mutual trust-building between management and employees. In support of this assertion, Ombe (2018) argued that staff motivation and job performance within organization promote interdependency among employers, employees, and customers. It leads to an increase of efficient 
productivity and promote the image of the organization towards its mission statements. It also promotes staff strength towards efficient and effective service delivery process. Seimode (2018) asserted that the end results of employees' motivation and job performance in organizations involve:

Increased productivity through the application of standard work methods.

Encouraging hard work among employees for achieving organizational objectives.

Helps in the proper use of time management and this enables workers to maximize their time for more pay.

Improvement of new skills towards increasing organizational effectiveness.

It helps in enhancing effectiveness and efficiency for the achievement of organizational goals.

It enables workers to be encouraged in meeting up their targets for recognition, rewards and these enable management to increase staff pay and promotion.

It leads to a high level of increase in profits, growth and encourages standard stable organization, in addition, promotes the public image of the organization.

\section{Theoretical Framework}

In view of this research, this study anchored on the Herzberg's Two Factor Theory of Motivation which is also referred to as the Motivation-Hygiene Theory. This theory was propounded by Frederick Herzberg, he carried out this research with his associate through an interview he conducted of 200 Engineers and Accountants working in eleven different firms in the Pittsberg area of the USA. However, for effective job performance to increase productivity in the organization there are two factors and the findings revealed that there are two sets of factors which affect satisfaction or dissatisfaction of employees (Saleemi and Bogonko, 1997) (Cited in Natolooka, 2010: 126).

The first set consists of Dissatisfies' or Hygiene Factors' or Maintenance Factors: these, according to Herzberg, are extrinsic and do not motivate employees in any way but dissatisfy employees when and if they are absent.

They include:

a. Company policy and administration;

b. Technical supervision;

c. Interpersonal relations with superiors, subordinates, and peers;

d. Working conditions;

e. Salary;

f. Job security;

g. Status;

h. Personal life.

The other set is called Motivational Factors: these are related to the content of the job, i.e., they are inherent in the job rather than in the surrounding environment. They include:

a. Feeling of achievement;

b. Recognition;

c. Challenging work itself;

d. Advancement;

e. Increased responsibility;

f. Opportunity for growth.

According to Herzberg, what motivate employees are only "Motivation Factors", "Hygiene Factors" do not in any way motivate employees. This study, therefore, premised on the curiosity to establishing the nexus between motivation and staff performance in the organization. 
ISSN (online) - 2520-6311; ISSN (print) - 2520-6761

The relevant of this framework to the analysis of motivation and staff performance in the organization is evident. The framework enlightens our understanding of how workers are highly induced to increase productivity within the organization and how the employees would be conditioned by management to improve efficiency and service delivery within the organization.

The framework made us understand that Herzberg analysis revealed that organizations should endeavor to establish ways on how employers would effectively recognize staff, provide responsibilities, create opportunities for advancement and these would usher in job satisfaction which is the motivational factors or satisfiers because organizations are deliberately set up to achieve some certain goals. For Basu (2012) in support of the arguments the motivators have a much long-lasting effect on sustaining satisfaction than the hygiene factors have on preventing dissatisfaction. The motivators in a work experience tend to be more selfsustaining and are not dependent upon constant supervisory attention. Hygiene needs, however, are related to things for which our appetites are never satisfied completely. Applications of hygiene improvement must be constantly reapplied, since the need for them always recurs, usually with increased intensity. Hygiene must always be replenished. Most of the methods used in work-related organizations to 'purchase' motivated behaviour over the years have appeared to be ineffective since the traditional motivation problems still exist. This is the inevitable result because only the things that surround the work itself were being improved, and these things have no lasting effect on the motivation of workers. Based on this analysis, Herzberger's framework exposes and usher in new insights into organizational behaviour on the issues of staff performance and motivation and he greatly emphasizes on job enrichment.

\section{Methodology}

The method adopted in this research work was a mixed approach. The population comprised the staff of University of Africa, Toru-Orua and Market Square Company in Bayelsa State and a sample size of 100 was chosen from both organizations because the study utilized focus group technique to ascertain the level of motivation and staff performance in the organization.

Table 1. The number of respondents from the University of Africa, Bayelsa State

\begin{tabular}{|c|l|c|}
\hline S/N & \multicolumn{1}{|c|}{ Faculties/Departments/Units } & Number of staff \\
\hline 1 & Social and Mgt Sciences/Arts and Education & 10 \\
\hline 2 & Agriculture /Applied and Pure Sciences & 10 \\
\hline 3 & Registry/Legal/ Bursary & 15 \\
\hline 4 & Library Department & 5 \\
\hline 5 & Security & 5 \\
\hline 6 & Clinic & 5 \\
\hline Total & & 50 \\
\hline
\end{tabular}

Source: Field Survey 2019

Table 2. The number of respondents from the Market Square, Bayelsa State

\begin{tabular}{|c|l|c|}
\hline S/N & \multicolumn{1}{|c|}{ Departments/Units } & Number of staff \\
\hline 1 & Food (Bakery, kitchen) & 20 \\
\hline 2 & Non-Food (Account, Adm, Security) & 15 \\
\hline 3 & Fresh Food (frozen, Preservation) & 15 \\
\hline Total & & 50 \\
\hline
\end{tabular}

Source: Field Survey 2019

\section{Comparative Analysis/Findings}

University of Africa, Toru Orua, Bayelsa State is a Public University owned, managed by Bayelsa State government. It was established by the Bayelsa State Government through a bill passed by the State House of Assembly and assented to by His Excellency and the Visitor to the University Honourable Henry Seriake Dickson on Friday, July 22, 2016. With effect from Thursday, July 28, 2017, the National University Commission NUC recognized the University of Africa, Toru-Orua as the $43^{\text {rd }}$ State University, and $143^{\text {rd }}$ in the Nigerian University System and the University started with 21 departments domiciled in the faculty of Social and Management Sciences, Pure and Applied Sciences, Agricultural Sciences, Arts and Education. The Major Objectives of theUniversity of Africa are; Learner-centered teaching-learning modules through the provision of innovative education that engenders personal creativity, building a strong capacity for selfsustenance through public-private partnership for fund generation and endowment, engagement of internationally qualified academic professionals in the delivery the varied learning experience to provide international exposure, etc. While its vision is to be the first-rate university committed to teaching and 
research excellence and dedicated to generating knowledge for innovation and service, while the motto of the university is Cognitio, Deligentia, Servitium in Latin, which means "Knowledge, Dignity and Service" in the English Language.

On the other hand, Market Square is Nigeria's emerging grocery retail chain and the company started operations in January 2016 in Bayelsa. The Market Square is a place where Nigerians go to find their trusted brands of groceries at the best prices. The Market Square was conceived from a burning sensation to create a modern and relevant retail shopping experience for Nigerians and a more convenient way for people to get their everyday needs.

Market Square provides a wide variety of prepared and packed food, fresh bakes, fresh produce, groceries, wines \& spirits, toiletries, baby products, and small domestic appliances, to serve the daily needs of individuals, households and corporate organizations. The vision of Market Square is to create a one-stop destination source for home cooking, home, and personal care. While the mission is to be the foremost indigenous grocery retail company using available local resources to bring products and customers together in a modern marketplace for the benefit of all stakeholders and the core values of Market Square comprises Trust, Service, Integrity, Initiative, Teamwork, Leadership Accountability.

However, respondents were interrogated on the various techniques and Packages that the University of Africa and Market Square uses to motivate and keep them geared towards high performance. They responded to the following motivational packages as follows:

a) Provision of loans - All the respondents in the University of Africa agreed that their organization gave them loans which are motivating in a sense that they are not only convenient but interest-free. They cited four loan types: Salary advance (pay within 6 months); Rent advance (pay within a year); Housing loans and car loans. But this was not applicable in the Market Square Company except salary advance.

b) Increment of level - all the respondents agreed that the University of Africa made increment of level within six months to all staff and all respondents in Market Square Company said they did not benefit from level increment among staff.

c) Promotions - This is another good motivator which all respondents cited, and this arises with some of the factors: availability of a higher vacant post which used to be filled by junior staff without discrimination but based on capability, selecting members of staff in different committees in the University, promotion of staff as coordinators and when promoted or given additional positions, they get more enthused and motivated to work harder because their working efforts are appreciated. But these packages are lacking in the Market Square Company except a change of positions/duties and also duty shift among workers in the organization.

d) Provision of Training opportunities - 50 Respondents agreed that staff of the University of Africa has been given many opportunities for training, also attended many workshops and conferences ranging from academic staff to non-academic staff irrespective of the level but at the Market Square 10 respondents agreed that training only took place within the senior staff in the organization and others remain untrained.

e) Provision of medical services - All the respondents agreed that the entire university of Africa enjoy full medical services through the university medical clinic and the State Health Insurance Scheme and not only medical services to the employees but also to staff immediate family members or relatives but at the Market Square company all respondents said that no such benefit in their organization.

f) Provision of good working and enabling environment - 45 respondents disagreed that the University of Africa is yet to provide staff with a good conducive working environment pending when they would be moving to their permanent site. But 45 of the respondents responded that Market Square staff has not been provided with a good working environment.

g) Paid leave - 50 respondents agreed that the University of Africa usually gives paid leave to staff every year but in the Market Square no such provision exists.

h) Special recognition among staff - All respondents in the University of Africa's staff agreed that there is a special recognition given to staff in all activities carried out by employees but this aspect was lacking in the Market Square company according to 40 of the respondents. 
Business Ethics and Leadership, Volume 3, Issue 3, 2019

ISSN (online) - 2520-6311; ISSN (print) - 2520-6761

i) Christmas bonus - 50 Respondents agreed that the University of Africa since inception has been paying Christmas bonus to all members of staff but 40 respondents in the Market Square said no such benefits exist and there was nothing like Christmas bonus in even 2018.

j) Formation of Staff welfare association - All the respondents said that management did not allow the formation of welfare associations to press their demands if the need arises in both the University of Africa and Market Square.

\section{Conclusion}

Staff motivation in an organization provides a very important role in high job performance and productivity. Motivation and job satisfaction lead to improvement of high job productivity and in addition, promote staff retention in organizations because employees' behaviour and feelings within the context of an organization are usually determined by the factors of motivation and job satisfaction and this is important for an organization to achieve and sustain themselves towards competition within other organizations.

The study concludes that there is a strong link between motivation and job satisfaction in both organizations and employees' performance towards effective and high productivity is as a result of the level of both management and staff commitment because low level of job satisfaction bring down staff morale on the job and there should be advancement and improvement of workers activities if employees are highly considered. More so, another important factor affecting the level of job satisfaction of employees centered through compensation package which maximizes high productivity within the organization and monetary and nonmonetary rewards provide a strong means of motivating employees towards job commitment and satisfaction.

\section{Recommendations}

The following recommendations were made in order to improve staff motivation as regards to employees' performance in projecting the image of both organizations.

1. The study recommends that employee should be involved in participation in pay consideration, regular payment of salaries, bonuses and other incentives to prevent bad effects on the performance of staff and other pertinent issues per equity of salaries.

2. Both organizations should always review their remuneration packages in order to attract good job satisfaction processes between members of their staff for high productivity.

3. Regular training and development opportunities should be made available for their staff for them to be effective in service delivery.

4. There should be a mutual relationship between management and workers for effective and efficient service delivery within the organization and the delegation of responsibilities for the increase in employees' performance.

5. Both organizations should form staff welfare associations in confronting management with their demands, which will enable management staff to easily attend to them, which would not call for any industrial action or riots.

\section{References}

1. Akpotohwo, F.C., Ogeibiri C, \& George, S.C. (2017). Organizational behaviour, principles and practice. Beau Bass: Lambert Academic Publishing.

2. Anonymous, (2010). Retrieved from: http://www.bsm.gov.tr/kalite/08/asp?sira=8 10/12/2018.

3. Basu, R. (2012). Public administration, concepts and theories. New Delhi: Sterling Publishers.

4. Calvin, O.Y (2017). HR practices and job performance. IOSR Journals, 19(4), 34-36. Available at: www.isorjournals.org/iosr-jhss/papers/Vo119-issue4/version-1/JO19415561.

5. Campbell, J., Mccloy, R., Saga, C. (1993). A theory of performance, in Schmitt, C.W, and Borman, W.C.A (eds), Personnel selection in organizations. (35-70). San Francisco: Jossey Bass.

6. Dolan, S. and Linghan, T. (2008). Fundamentals of international organizational behaviour. USA: IBM.

7. Ezeani, E.O. (2006). Fundamentals of public administration. Enugu: Zik-Chuks Publisher.

8. Maicibi, N.A. (2007a). Human resources management success. Tips for HRM theories and practitioners: Kampala: Makerere Printery.

9. Maicibi, N.A. (2013b). Pertinent issues in employees' management. Kampala: SSP Uganda Ltd. 
10.Market Square opens in Yenagoa (2016). Retrieved from: https://marketsquireng.com/marketsquireopens-in-yenagoa. 25/12/2018.

11.Market Square about us (2018). Retrieved from: https://marketsquareng.com/ 20/12/2018.

12.Natolooka, K. (2010). Applicability of Herzberg's two factors theory of motivation to bank of Uganda. KIU Journal of Social Sciences, 1(1), 125-132.

13.Nidhi (2015). Work motivation and job performance. A comparative study of some selected public and private banks in India. International Journal of Applied Research, 1(6), 302- 313.

14.Okiswa, G. \& Oketchi, C. (2016). Motivation and job satisfaction among employees of Kampala university study centers of Masaka, Luwero and Jinja. KIU Journal of Social Sciences, 2(1), 50-61.

15.Salanova, A. \& Kirmanen, S. (2010). Employee satisfaction and work motivation. Bachelor Thesis, Business Management. Research in Prisma Mikkeli. Mikkeli University of Applied Sciences.

16.Singh, S.K. \& Tiwari, V. (2010). Relationship between motivation and job satisfaction of the white collar employees: A case study. Management Insight, V11(2), 1-39.

17.Spector, P.E. (1997). Job satisfaction-application, assessment, causes and consequences. Thousand Oak CA: SAGE Publications.

18.Thump-Otuya, V. (2003). Lecture Notes on Principles of Management. Rivers State College of Education, Port-Harcourt.

19.University of Africa, Toru-Orua, Bayelsa State. $1^{\text {st }}$ Orientation Programme for 2017-2018 Academic Session Handbook.

20.University of Africa, Toru-Orua, Bayelsa State, Nigeria. An Address at The Maiden Matriculation Ceremony and $1^{\text {st }}$ Distinguished Public Lectures Series of University of Africa, Toru-Orua, Bayelsa State, Nigeria, April 21, 2018. 